\title{
HUBUNGAN PEMBERIAN MAKANAN PADAT DINI DENGAN KEJADIAN DIARE PADA BAYI DI RSUD AMBARAWA
}

\author{
Risang Bhaskoro', Bambang Mulyawan ${ }^{2}$ \\ Fakultas Kedokteran Universitas Muhammadiyah Malang, J1. Bendungan Sutami No. 188A, Kota Malang, \\ 65145, Indonesia, 0341-551149
}

\begin{abstract}
ABSTRAK
Hubungan Pemberian Makanan Padat Dini Dengan Kejadian Diare Pada Bayi di RSUD Ambarawa Latar Belakang: Diare diartikan sebagai buang air besar yang tidak normal atau bentuk tinja yang encer dengan frekuensi lebih banyak dari biasanya. Neonatus dinyatakan diare bila frekuensi buang air besar sudah lebih dari 4 kali, sedangkan untuk bayi berumur lebih dari 1 bulan dan anak, bila frekuensinya lebih dari 3 kali sehari. Bayi yang tidak diberi ASI eksklusif mempunyai kemungkinan 14,2 kali lebih sering terkena diare dibandingkan dengan bayi yang mendapat ASI eksklusif. Tujuan: Mengetahui hubungan pemberian makanan padat dini dengan kejadian diare pada bayi di RSUD Ambarawa. Metode: Observasi analitik dengan pendekatan cross sectional. Pengambilan sampel dengan teknik total sampling. Jumlah sampel 39. Dianalisis dengan uji Chi-Square dan koefisien kontingensi. Hasil Penelitian: 69,2\% ibu memberikan makanan padat, 51,3\% bayi mengalami diare dan $17,9 \%$ bayi tidak mengalami diare. Sedangkan 30,8\% ibu yang tidak memberikan makanan padat, 5,1\% bayi mengalami diare dan 25,6\% bayi tidak mengalami diare, dengan nilai p sebesar 0,001, nilai $r$ sebesar 0,471 dan RR =4,44 \{95\% CI: $(1,82-10,72)\}$. Kesimpulan: Ada hubungan antara pemberian makanan padat dini dengan kejadian diare pada bayi di RSUD Ambarawa.
\end{abstract}

\section{ABSTRACT}

The Relationship Between Early Solid Food Feeding With Diarrhea Incidence In Infants In General Hospital of Ambarawa. Background: Diarrbea is defined as abnormal bowel movement or passing of watery stools more frequently than usual. Neonates are considered to have diarrhea when the frequency of bowel movement is more than 4 times. Meanwhile, for infants older than 1 month and a child, diarrhea is diagnosed if the frequency of bowel movement is more than 3 times a day. Infants that are not been given exclusive breast milk have the probability of suffering from diarrbea 14,2 times compared to the infants that are breast feeded with exclusive breast milk. Objective: To indentify the relationship between Early Solid Food Feeding with Diarrhea incidence in infants in General Hospital of Ambarawa. Method: Analytic Observation with cross sectional approach. Total sampling technique has been used. Number of samples was 39. The result was analyzed by using Chi-square and contingency coefficient. Results: 69.2\% from the number of mothers that gave solid food to their babies, there was $51.3 \%$ of the number of babies that experienced diarrbea and $17.9 \%$ of them did not experience diarrhea. Whereas $30.8 \%$ of the number of mothers who did not give solid food to their babies, $5.1 \%$ of the infants had diarrhea and $25.6 \%$ of them did not get diarrhea, with $P$ values of $0.001, R$ value of 0.471 and $R R=$ 4,44 \{95\% CI: $(1,82-10,72)\}$. Conclusion: There was relationship between early solid food feeding in infants with the incidence of diarrbea in General Hospital of Ambarawa.

Key words: Early solid food feeding, diarrhea, infant.

\section{PENDAHULUAN}

Diare adalah defekasi encer lebih dari 3 kali sehari, dengan/tanpa darah dan/atau lendir dalam tinja (Suharyono, Boediarso \& Halimun 1999). Neonatus dinyatakan diare bila frekuensi buang air besar sudah lebih dari 4 kali, sedangkan untuk bayi berumur lebih dari 1 bulan dan anak, bila frekuensinya lebih dari 3 kali sehari (Hassan \& Napitupulu 2007). Diare dapat disebabkan oleh infeksi virus, bakteri, parasit, jamur, hiperperistaltik usus halus yang dapat disebabkan oleh bahan kimia makanan, gangguan psikis, alergi, defisiensi imun terutama SIgA (secretory Immunoglobulin A) (Suharyono, Boediarso \& Halimun 1999). Selain itu diare terjadi karena malabsorpsi dari solut (Soeparto et al, 1999). Akibat terdapat makanan atau zat yang tidak dapat diserap akan menyebabkan tekanan osmotik dalam rongga usus meninggi, sehingga terjadi pergeseran air dan elektrolit ke dalam rongga usus. Isi rongga usus yang berlebihan ini akan merangsang usus untuk mengeluarkannya sehingga timbul diare (Hassan \& Napitupulu 2007).

Pada era sekarang, 80\% bayi yang baru lahir di Indonesia tidak lagi menyusu selama 6 bulan. Padahal, pemberian makanan padat pada bayi dibawah usia 4 bulan sering menyebabkan gangguan diare (Kamalia 2005). Di daerah pedesaan Indonesia seperti di Blitar, Jawa Timur, 80\% ibu memberikan makanan padat dini pada bayi yang baru lahir berupa pisang. Di Pulau Lombok, NTB, 94\% ibu memberikan makanan padat dini berupa pisang, nasi, bubur tepung. Semua ini menggambarkan bahwa pemberian 
makanan padat dini merupakan suatu kebiasaan yang terjadi di masyarakat yang sangat berhubungan dengan sosial ekonomi yang rendah. Setelah melahirkan dan sebelum bayinya berusia 4 bulan, ibu harus bekerja baik sebagai buruh tani (daerah rural) ataupun sebagai buruh pabrik (daerah urban) (Wiryo 2005). Mengingat besarnya akibat dari pemberian makanan padat yang terlalu dini dengan kejadian diare, perlu perhatian yang cukup terhadap masalah ini.

Penelitian ini bertujuan untuk mengetahui hubungan pemberian makanan padat dini dengan kejadian diare pada bayi di RSUD Ambarawa. Diharapkan penelitian ini dapat menjadi sumber data epidemiologi terbaru mengenai perkembangan insiden kejadian diare di RSUD Ambarawa dan juga lebih memperhatikan pengetahuan ibu mengenai pentingnya pemberian ASI ekslusif dan pemberian makanan bayi sesuai pada waktunya. Serta dapat memberi informasi dan pengetahuan kepada masyarakat terutama ibu mengenai pentingnya pemberian ASI ekslusif dan penundaan pemberian MP-ASI agar terhindar dari penyakit diare.

\section{METODE}

\section{Alat dan Bahan}

Alat dan bahan yang digunakan dalam penelitian ini adalah data primer yaitu kuesioner tertutup (close ended item) untuk mengetahui informasi mengenai pemberian makanan padat dini dan kejadian diare (Notoatmodjo 2005).

\section{Uji Validitas dan Realibilitas Kuesioner}

Uji validitas dilakukan untuk mengetahui sejauh mana alat dan bahan penelitian dapat mengukur apa yang seharusnya diukur, sesuai dengan yang dimaksudkan oleh peneliti, dengan kata lain untuk mengetahui apakah item pertanyaan yang ada pada kuesioner valid dan dapat digunakan untuk mengumpulkan data. Data yang telah dikumpulkan dengan menggunakan kuesioner akan diuji validitasnya menggunakan hubungan korelasi Product Moment dengan bantuan komputer, pada program SPSS for windows. Karena kuesioner ini diujikan pada 20 sampel, maka dapat dikatakan valid jika r-hitung $>$ dari r-tabel 0,444 .

Uji reliabilitas dilakukan untuk mengetahui sejauh mana alat dan bahan penelitian yang digunakan dapat dipercaya. Hal ini berarti menunjukkan sejauh mana hasil pengukuran itu tetap konsisten bila dilakukan pengukuran dua kali atau lebih terhadap gejala yang sama dengan menggunakan alat dan bahan penelitian yang sama (Notoatmodjo 2005). Data yang telah dikumpulkan dengan menggunakan kuesioner, akan diuji reliabilitasnya menggunakan rumus Cronbach's Alpha dengan bantuan komputer, pada program SPSS for windows. Karena kuesioner ini diujikan pada 20 sampel, maka dapat dikatakan reliabel jika $A \not p h a>$ dari r-tabel 0,666.

\section{Pengumpulan Data}

Dimulai dengan menentukan sampel di poli anak RSUD Ambarawa, setelah memenuhi kriteria inklusi diberi informed consent, kemudian dilakukan pemberian kuesioner kepada responden (ibu) bayi untuk mengetahui informasi mengenai pemberian makanan padat dini dan kejadian diare pada bayi. Setiap responden mendapatkan kuesioner dan tata cara pengisian yang sama dengan mengisi sendiri kuesioner yang telah diberikan (Notoatmodjo 2005).

\section{Analisis Data}

Data yang diperoleh dari kuesioner dikumpulkan dalam bentuk tabel distribusi frekuensi. Data dianalisis dengan menggunakan program SPSS release 12, untuk menentukan ada tidaknya hubungan pemberian makanan padat dini dengan kejadian diare pada bayi dilakukan uji Chi-Square dan untuk menentukan seberapa signifikan korelasi antara dua variabel dilakukan uji korelasi koefisien kontingensi (Sopiyudin 2009).

Untuk menghitung besar risiko relatif (RR) menggunakan tabel di bawah ini (Chandra 2008):

Tabel 1. Risiko Relatif

\begin{tabular}{llll}
\hline $\begin{array}{l}\text { Faktor } \\
\text { risiko }\end{array}$ & Diare & $\begin{array}{l}\text { Tidak } \\
\text { diare }\end{array}$ & Jumlah \\
Positif & a & b & mi \\
Negatif & c & d & mo \\
Jumlah & ni & no & t \\
\hline
\end{tabular}

(Chandra, 2008)

Dengan menggunakan rumus risiko relatif (RR) yaitu:

a. Uji chi-square

$\mathrm{x} 2=(\mathrm{t}-1)[(\mathrm{ad})-(\mathrm{bc})]^{2}$

ni.no.mi.mo

b. Interval kepercayaan (95\%) RR :

Upper $=\mathrm{RR}(1+\mathrm{Z} / \mathrm{x})$

Lower $=\mathrm{RR}(1-\mathrm{Z} / \mathrm{x})$

Interpretasi OR :

$\mathrm{RR}=1$, diperkirakan tidak ada asosiasi antara faktor risiko dan penyakit.

$\mathrm{RR}>1$, diperkirakan terdapat asosiasi positif antara faktor risiko dan penyakit.

$\mathrm{RR}<1$, diperkirakan terdapat asosiasi negatif antara faktor risiko dan penyakit.

\section{HASIL DAN PEMBAHASAN}

Berdasarkan hasil penelitian yang dilakukan terhadap seluruh bayi usia 0-6 bulan yang berobat di RSUD Ambarawa pada bulan Desember 2010, didapatkan jumlah sampel sebanyak 39 bayi yang memenuhi kriteria inklusi dan eksklusi yang telah ditetapkan oleh peneliti. Data yang diperoleh merupakan data primer yaitu data yang berasal dari hasil pemberian kuesioner tertutup (close ended item) kepada ibu bayi usia 0-6 bulan yang berobat di RSUD Ambarawa pada bulan Desember 2010 dapat dilihat pada tabel 2 di bawah ini:

\section{Tabel 2. Pembagian Sampel}

$\begin{array}{lll}\begin{array}{l}\text { Pemberian } \\ \text { makanan }\end{array} & \text { Frekuensi } & \text { Persentase } \\ \text { padat } & & \\ \text { Ya } & 27 & 69,2 \% \\ \text { Tidak } & 12 & 30,8 \% \\ \text { Jumlah } & 39 & 100 \%\end{array}$


Distribusi sampel berdasarkan usia dapat dilihat pada tabel 3 di bawah ini:

Tabel 3. Usia Sampel

\begin{tabular}{lllll}
\hline Usia & \multicolumn{3}{l}{ Pemberian Makanan Padat } \\
& Ya & \multicolumn{3}{c}{ Tidak } \\
1-2 bulan 2- & 4 & $10,2 \%$ & 6 & $15,4 \%$ \\
3 bulan 3-4 & 0 & $0 \%$ & 3 & $7,7 \%$ \\
bulan 4-5 & 3 & $7,7 \%$ & 2 & $5,1 \%$ \\
bulan 5-6 & 4 & $10,2 \%$ & 0 & $0 \%$ \\
bulan & 16 & $41,1 \%$ & 1 & $2,6 \%$ \\
Jumlah & 27 & $69,2 \%$ & 12 & $30,8 \%$ \\
\hline
\end{tabular}

Berdasarkan hasil observasi, untuk memberikan gambaran secara umum mengenai informasi dari ibu bayi (0-6 bulan) yang berobat di RSUD Ambarawa bulan Desember 2010 diperoleh informasi mengenai frekuensi pemberian ASI, frekuensi pemberian makanan padat, lama pemberian ASI, usia pemberian makanan padat, alasan pemberian makanan padat dini, kejadian diare dari lahir sampai dilakukan penelitian, lama diare, kejadian diare waktu penelitian dan penyakit sebelum menderita diare.

Deskriptif karakteristik responden berdasarkan frekuensi pemberian ASI dapat dilihat pada tabel 4 sebagai berikut:

\section{Tabel 4. Karakteristik Responden Berdasarkan Frekuensi Pemberian ASI}

\begin{tabular}{lllll}
\hline Pemberian & \multicolumn{3}{l}{ Pemberian Makanan Padat } \\
ASI & Ya & \multicolumn{3}{c}{ Tidak } \\
$0-1$ kali & 0 & $0 \%$ & 0 & $0 \%$ \\
$2-3$ kali & 4 & $10,2 \%$ & 0 & $0 \%$ \\
$>3$ kali & 12 & $30,8 \%$ & 1 & $2,6 \%$ \\
$\begin{array}{l}\text { Setiap saat } \\
\text { bayi merasa }\end{array}$ & 11 & $28,2 \%$ & 11 & $28,2 \%$ \\
lapar & & & & \\
$\begin{array}{l}\text { Tidak } \\
\text { memberi }\end{array}$ & 0 & $0 \%$ & 0 & $0 \%$ \\
$\begin{array}{l}\text { ASI } \\
\text { Jumlah }\end{array}$ & 27 & $69,2 \%$ & 12 & $30,8 \%$ \\
\hline
\end{tabular}

Deskriptif karakteristik responden berdasarkan jumlah pemberian makanan padat yang dapat dilihat pada tabel 5 di bawah ini:

\section{Tabel 5. Karakteristik Responden Berdasarkan Frekuensi Pemberian Makanan Padat}

\begin{tabular}{lll}
\hline $\begin{array}{l}\text { Frekuensi } \\
\text { Pemberian Makanan }\end{array}$ & Jumlah & $\begin{array}{l}\text { Persen- } \\
\text { tase }\end{array}$ \\
$\begin{array}{l}\text { Padat } \\
0-1 \text { kali }\end{array}$ & 3 & $7,7 \%$ \\
$2-3$ kali & 15 & $38,4 \%$ \\
$>3$ kali & 6 & $15,4 \%$ \\
$\begin{array}{l}\text { Setiap saat bayi } \\
\text { merasa lapar }\end{array}$ & 3 & $7,7 \%$ \\
$\begin{array}{l}\text { Tidak memberi } \\
\text { makanan padat }\end{array}$ & 0 & $0 \%$ \\
Jumlah & & \\
\hline
\end{tabular}

Deskriptif karakteristik responden berdasarkan usia pemberian ASI yang dapat dilihat pada tabel 6 sebagai berikut:
Tabel 6. Karakteristik Responden Berdasarkan Lama Pemberian ASI

\begin{tabular}{|c|c|c|c|c|}
\hline Lama & \multicolumn{4}{|c|}{ Pemberian Makanan Padat } \\
\hline $\begin{array}{l}\text { Pemberian } \\
\text { ASI }\end{array}$ & \multicolumn{2}{|l|}{ Ya } & \multicolumn{2}{|c|}{ Tidak } \\
\hline 1-2 bulan & 8 & $20,5 \%$ & 6 & $15,4 \%$ \\
\hline $2-3$ bulan & 4 & $10,3 \%$ & 3 & $7,7 \%$ \\
\hline 3-4 bulan & 9 & $23 \%$ & 2 & $5,1 \%$ \\
\hline 4-5 bulan & 3 & $7,7 \%$ & 0 & $0 \%$ \\
\hline $5-6$ bulan & 3 & $7,7 \%$ & 1 & $2,6 \%$ \\
\hline Jumlah & 27 & $69,2 \%$ & 12 & $30,8 \%$ \\
\hline
\end{tabular}

Deskriptif karakteristik responden berdasarkan usia pemberian makanan padat yang dapat dilihat pada tabel 7 sebagai berikut:

Tabel 7. Karakteristik Responden Berdasarkan Usia Pemberian Makanan Padat Dini

\begin{tabular}{lll}
\hline Usia Pemberian & Jumlah & Persentase \\
Makanan Padat & & \\
Tidak pernah & 0 & $0 \%$ \\
0-1 bulan & 5 & $12,8 \%$ \\
2-3 bulan & 8 & $20,5 \%$ \\
4-5 bulan & 12 & $30,8 \%$ \\
6 bulan & 2 & $5,1 \%$ \\
Jumlah & 27 & $69,2 \%$ \\
\hline
\end{tabular}

Alasan pemberian makanan padat dapat dilihat pada tabel 8 sebagai berikut:

Tabel 8. Alasan Pemberian Makanan Padat Dini

\begin{tabular}{lll}
\hline $\begin{array}{l}\text { Alasan Pemberian } \\
\text { Makanan Padat }\end{array}$ & Jumlah & $\begin{array}{l}\text { Persen- } \\
\text { tase }\end{array}$ \\
Tidak pernah & 0 & $0 \%$ \\
Ibu bekerja & 8 & $20,5 \%$ \\
Kebiasaan di masyarakat & 2 & $5.1 \%$ \\
Bayi masih lapar/rewel & 11 & $28,2 \%$ \\
terus & & \\
ASI tidak keluar & 6 & $15,4 \%$ \\
Jumlah & 27 & $69,2 \%$ \\
\hline
\end{tabular}

Deskriptif karakteristik responden berdasarkan kejadian diare dari lahir sampai dilakukan penelitian yang dapat dilihat pada tabel 9 sebagai berikut:

Tabel 9. Karakteristik Responden Berdasarkan Kejadian Diare dari Lahir sampai Dilakukan Penelitian

\begin{tabular}{llccc}
\hline Kejadian Diare & \multicolumn{4}{l}{ Pemberian Makanan Padat } \\
$\begin{array}{l}\text { Dari Lahir Sampai } \\
\text { Dilakukan }\end{array}$ & Ya & \multicolumn{3}{c}{ Tidak } \\
$\begin{array}{l}\text { Penelitian } \\
\text { Tidak pernah }\end{array}$ & 1 & $2,6 \%$ & 3 & $7,7 \%$ \\
menderita diare & & & & \\
Pernah (1 kali) & 4 & $10,2 \%$ & 4 & $10,3 \%$ \\
Jarang (2-3 kali) & 12 & $30,8 \%$ & 5 & $12,8 \%$ \\
Sering (4-5 kali) & 9 & $23 \%$ & 0 & $0 \%$ \\
Sangat sering (>5 & 1 & $2,6 \%$ & 0 & $0 \%$ \\
kali) & & & & \\
Jumlah & 27 & $69,2 \%$ & 12 & $30,8 \%$ \\
& & & &
\end{tabular}


Deskriptif karakteristik responden berdasarkan lama diare yang dapat dilihat pada tabel 10 sebagai berikut:

Tabel 10. Karakteristik Responden Berdasarkan Lama Diare

\begin{tabular}{lllll}
\hline Lama & \multicolumn{3}{l}{ Pemberian Makanan Padat } \\
Diare & Ya & \multicolumn{3}{c}{ Tidak } \\
Tidak & 1 & $2,6 \%$ & 3 & $7,7 \%$ \\
pernah & & & & \\
1-3 hari & 22 & $56,4 \%$ & 9 & $23,1 \%$ \\
4-7 hari & 4 & $10,2 \%$ & 0 & $0 \%$ \\
7-14 hari & 0 & $0 \%$ & 0 & $0 \%$ \\
>14 hari & 0 & $0 \%$ & 0 & $0 \%$ \\
Jumlah & 27 & $69,2 \%$ & 12 & $30,8 \%$
\end{tabular}

Deskriptif karakteristik responden berdasarkan kejadian diare waktu penelitian yang dapat dilihat pada tabel 11 sebagai berikut:

Tabel 11. Karakteristik Responden Berdasarkan Kejadian Diare Waktu Penelitian

\begin{tabular}{lllll}
\hline Kejadian & \multicolumn{3}{l}{ Pemberian Makanan Padat } \\
$\begin{array}{l}\text { Diare Waktu } \\
\begin{array}{l}\text { Penelitian } \\
\text { Tidak }\end{array}\end{array}$ & Ya & \multicolumn{3}{c}{ Tidak } \\
$\begin{array}{l}\text { menderita } \\
\text { diare }\end{array}$ & & $18 \%$ & 10 & $25,7 \%$ \\
1-3 hari & 17 & $43,5 \%$ & 0 & $0 \%$ \\
4-7 hari & 3 & $7,7 \%$ & 0 & $0 \%$ \\
7-14 hari & 0 & $0 \%$ & 0 & $0 \%$ \\
$>14$ hari & 0 & $0 \%$ & & \\
Jumlah & 27 & $69,2 \%$ & 12 & $30,8 \%$ \\
\hline
\end{tabular}

Deskriptif karakteristik responden berdasarkan penyakit sebelum diare yang dapat dilihat pada tabel 12 sebagai berikut:

Tabel 12. Karakteristik Responden Berdasarkan Penyakit Sebelum Diare

\begin{tabular}{lllll}
\hline Penyakit & \multicolumn{3}{c}{ Pemberian Makanan Padat } \\
Sebelum Diare & Ya & \multicolumn{3}{c}{ Tidak } \\
$\begin{array}{l}\text { Tidak pernah } \\
\text { menderita diare }\end{array}$ & 1 & $2,6 \%$ & 3 & $7,7 \%$ \\
$\begin{array}{l}\text { Panas tinggi } \\
\text { Sariawan }\end{array}$ & 5 & $12,8 \%$ & 3 & $7,7 \%$ \\
$\begin{array}{l}\text { (gommen) } \\
\text { Batuk, pilek }\end{array}$ & 2 & $5,1 \%$ & 1 & $2,6 \%$ \\
$\begin{array}{l}\text { Tidak ada } \\
\text { Jumlah }\end{array}$ & 13 & $15,4 \%$ & 5 & $12,8 \%$ \\
\hline
\end{tabular}

Hubungan pemberian makanan padat dini dengan kejadian diare dapat dilihat pada tabel di bawah ini:

\section{Tabel 13. Hubungan Pemberian Makanan Padat Dini Dengan Kejadian Diare}

\begin{tabular}{lllll}
\hline $\begin{array}{l}\text { Pemberian } \\
\text { makanan } \\
\text { padat }\end{array}$ & Diare & & Tidak diare \\
Ya & 20 & $51,3 \%$ & 7 & $17,9 \%$ \\
Tidak & 2 & $5,1 \%$ & 10 & $25,7 \%$ \\
Jumlah & 27 & $56,4 \%$ & 12 & $43,6 \%$ \\
& & & &
\end{tabular}

Berdasarkan hasil Penelitian yang dilakukan terhadap seluruh bayi usia 0-6 bulan yang berobat di RSUD Ambarawa pada bulan Desember 2010, didapatkan jumlah sampel sebanyak 39 bayi, untuk menentukan ada tidaknya hubungan pemberian makanan padat dini dengan kejadian diare pada bayi dilakukan uji Chi-Square dan untuk menentukan seberapa signifikan korelasi antara dua variabel dilakukan uji korelasi koefisien kontingensi. Hasil uji Chi-Square diperoleh nilai signifikansi (p) sebesar 0,001 yang artinya menunjukkan bahwa ada hubungan antara pemberian makanan padat dini dengan kejadian diare pada bayi. Pada uji korelasi koefisien kontingensi diperoleh nilai kekuatan korelasi (r) 0,471 yang menyatakan bahwa derajat korelasi antara pemberian makanan padat dini dengan kejadian diare pada bayi adalah sedang.

Hasil perhitungan risiko relatif diperoleh $\mathrm{RR}=4,44$ $\{95 \%$ CI: $(1,82-10,72)\}$ yang artinya pada interval kepercayaan (CI) 95\%, nilai RR yang dihitung 4,44 masih berada dalam rentang nilai atas dan bawah sehingga terdapat asosiasi positif yang signifikan secara statistik antara faktor risiko pemberian makanan padat dini dengan kejadian diare pada bayi.

Berdasarkan hasil penelitian menunjukkan bahwa pada ibu yang memberikan makanan padat berjumlah $27 \mathrm{ibu}$ $(69,2 \%)$, dengan kejadian diare sejumlah 20 bayi $(51,3 \%)$ dan yang tidak mengalami diare sebanyak 7 bayi (17,9\%). Sedangkan ibu yang tidak memberikan makanan padat berjumlah $12 \mathrm{ibu}(30,8 \%)$, dengan kejadian diare sejumlah 2 bayi $(5,1 \%)$ dan yang tidak mengalami diare sejumlah 10 bayi $(25,6 \%)$.

Hasil tersebut sesuai dengan pernyataan Wiryo (2005) yang menyatakan bahwa pemberian makanan selain ASI akan mengurangi keinginan bayi untuk menyusu sehingga frekuensi dan kekuatan bayi dalam menyusu berkurang. Akibatnya produksi ASI berkurang, bayi kurang mendapatkan imun yang ada dalam ASI sehingga bayi menjadi mudah mengalami diare, infeksi saluran nafas hingga meningkatkan angka kematian bayi (AKB).

Dengan demikian diharapkan ibu lebih mengerti mengenai pemberian ASI eksklusif dan waktu yang tepat untuk memberikan makanan padat agar terhindar dari risiko yang didapatkan akibat dari pemberian makanan padat yang tidak tepat pada waktunya.

Berdasarkan hasil Penelitian yang dilakukan terhadap seluruh bayi usia 0-6 bulan yang berobat di RSUD Ambarawa pada bulan Desember 2010, didapatkan jumlah sampel sebanyak 39 bayi, untuk menentukan ada tidaknya hubungan pemberian makanan padat dini dengan kejadian diare pada bayi dilakukan uji Chi-Square dan untuk menentukan seberapa signifikan korelasi antara dua variabel dilakukan uji korelasi koefisien kontingensi. Pada uji Chi-Square diperoleh nilai signifikansi (p) sebesar 0.001 yang artinya menunjukkan bahwa ada hubungan antara pemberian makanan padat dini dengan kejadian diare pada bayi di RSUD Ambarawa dikarenakan nilai (p) dikatakan bermakna apabila nilai $\mathrm{p}<$ 0,05. Pada uji korelasi koefisien kontingensi pada penelitian ini didapatkan nilai kekuatan korelasi (r) sebesar 0,471 yang berarti bahwa korelasi antara pemberian makanan padat dengan kejadian diare pada bayi di RSUD Ambarawa adalah sedang. 
Hasil nilai (p) sebesar 0,001 dan nilai kekuatan korelasi (r) sebesar 0,471 pada penelitian ini menunjukkan bahwa terdapat hubungan antara pemberian makanan padat dini dengan kejadian diare pada bayi. Pardosi (2009) menyatakan bahwa dalam makanan tambahan biasanya terkandung konsentrasi tinggi karbohidrat dan gula yang masih sukar dicerna oleh organ pencernaan bayi apabila diberikan terlalu dini, karena produksi enzim khususnya amylase pada bayi masih rendah. Akibatnya terjadi malabsorpsi di dalam organ pencernaan bayi karena produksi enzim pencernaan masih rendah, sebagai akibatnya akan terjadi gangguan gastrointestinal pada bayi yang salah satunya adalah diare.

Sehingga dari hasil penelitian ini dapat diambil kesimpulan bahwa terdapat hubungan antara pemberian makanan padat dini dengan kejadian diare pada bayi di RSUD Ambarawa dengan kekuatan korelasi sedang.

Dari hasil perhitungan risiko relatif di atas pada interval kepercayaan (CI) 95\%, diperoleh nilai risiko relatif 4,44. Sehingga dapat disimpulkan, risiko diare pada bayi yang mendapatkan makanan padat dini adalah 4,44 kali lebih tinggi daripada bayi yang tidak mendapatkan makanan padat dini.

\section{SIMPULAN}

Terdapat pengaruh pemberian makanan padat dini dengan kejadian diare pada bayi di RSUD Ambarawa dengan kekuatan korelasi sedang. Risiko diare pada bayi yang mendapatkan makanan padat dini adalah 4,44 kali lebih tinggi daripada bayi yang tidak mendapatkan makanan padat dini. Kebanyakan ibu yang memberikan makanan padat, mulai memberikan makanan padat pada saat bayi berusia 4-5 bulan dan memiliki alasan karena merasa bayi masih lapar atau rewel terus.

\section{DAFTAR PUSTAKA}

Adisasmito, W 2007, Faktor Risiko Diare Pada Bayi dan Balita di Indonesia: Systematic Review Penelitian Akademik Bidang Kesehatan Masyarakat, viewed 27 Oktober 2009, (http://journal.ui.ac.id/upload/artikel/ 01_Wiku\% 20AS_FAKTOR\%20RISIKO $\% 20$ DIARE_ Revisi. PDF).

Apriyanti, M, Ikob, R, Fajar, NA 2009, Faktor-Faktor yang Berhubungan Dengan Kejadian Diare Pada Anak Usia 6-24 Bulan di Wilayah Kerja Puskesmas Swakelola 11 Ilir Palembang Tahun 2009, viewed 12 Desember 2010, (http://uppm.fkm.unsri.ac.id/uploads/files / u_2/Abstrak10.doc)

Baskoro, A 2008, ASI Panduan Praktis Ibu Menyusui, Banyu Media, Yogyakarta.

Behrman, RE, Kliegman, R, Arvin, AM 1999, Ilmu Kesehatan Anak, edisi 15,EGC, Jakarta.

Bonyata, K 2003, Solid Food and the Breastfed Baby, viewed 20 November 2009, (http://www.kellymom. com/nutrition/solids/solids-when.html).

Briawan, D 2004, Pengaruh Promosi Susu Formula Terhadap Pergeseran Penggunaan Air Susu Ibu (ASI), viewed 20 November 2009, (http://www.rudyct.com/PPS702ipb/09145/dodik_briawan.pdf).
Chandra, B 2008, Metodologi Penelitian Kesehatan, EGC, Jakarta.

Gunardi $\mathrm{H}$ et al, 2008, Bunga Rampai Tips Pediatrik, IDAI, Jakarta.

Hassan, R, Napitupulu, PM 2007, Buku Kuliah 1 Ilmu Kesehatan Anak, FKUI, Jakarta.

Hegar B et al, 2008, Bedah ASI, IDAI, Jakarta.

Juffrie, M 2009, Hipernatremia in Dhiarrheal Disease, In : Asian Conference On Diarrhoeal Disease And Nutrition, Yogyakarta, Mei.

Kamalia, D 2005, Hubungan Pemberian Asi Eksklusif Dengan Kejadian Diare Pada Bayi Usia 1-6 Bulan di Wilayah Kerja Puskesmas Kedungwuni I Tahun 2004/ 2005, viewed 9 September 2009,(http:// digilib.unnes.ac.id/gsdl/collect/skripsi/archives / HASH01da/90431471.dir/doc.pdf).

Lubis, NU 2000, Manfaat Pemakaian ASI Eksklusif, viewed 4 September 2010, (http:/ /www.kalbe.co.id/files/cdk/ files/12ManfaatPemakaianASIEksklusif126.pdf/ 12ManfaatPemakaianASIEksklusif126.html).

Subijanto et al, 2006, Managemen Diare Pada Bayi dan Anak, viewed 12 Oktober 2010, (http:// www.pediatrik.com/buletin/20060220-s05jfgbuletin.pdf).

Manik, M 2003, Keracunan Makanan, viewed 5 Desember 2010, (http://repository. usu.ac.id/ bitstream/ 123456789/3522/1/gizi-murniati.pdf).

Mayo Clinic Staff 2010, Antibiotic Associated Diarrhea, viewed 5 Desember 2010, (http://www.nlm.nih.gov/ medlineplus/diarrhea.html).

Murniningsih, Sulastri 2008, Hubungan Antara Pemberian Makanan Tambahan Pada Usia Dini Dengan Tingkat Kunjungan ke Pelayanan Kesehatan di Kelurahan Sine Sragen, viewed 16 Oktober 2010, (http:// eprints.ums.ac.id/1100/1/3c.pdf).

Notoatmodjo, S 2005, Metodologi Penelitian Kesehatan, edisi revisi, Rineka Cipta, Jakarta.

Pardosi, R 2009, Perilaku Ibu dalam Pemberian Makanan Tambahan pada Bayi Usia Kurang dari Enam Bulan di Kelurahan Mangga Perumnas Simalingkar Medan, viewed 25 Oktober 2010, (http://repository.usu.ac.id/ bitstream/123456789/14297/1/09E02620.pdf).

Pimental, R, Choure, A 2009, Antibiotic Associated Diarrhea, viewed 18 November 2010, (http:// www.clevelandclinicmeded.com/medicalpubs / diseasemanagement/gastroenterology/antibiotic-associated-diarrhea/\#bib16)

Roesli, U 2000, Mengenal Asi Eksklusif, Trubus Agriwidya, Jakarta.

Sastroasmoro, S, Sofyan, I 2008, Dasar-Dasar Metodologi Penelitian Klinis, Sagung Seto, Jakarta.

Siregar, A 2004, Pemberian Asi Ekslusif dan Faktor-Faktor yang Mempengaruhinya, viewed 20 November 2009, (http://library.usu.ac.id/download/fkm/fkmarifin4.pdf).

Soenarto, Y 2010, Peran Tata Laksana Diare Terkini Dalam Menurunkan Angka Kematian Anak Untuk Mencapai Millennium Development Goals (MDGs), IDAI, Jakarta. Soenarto, Y 2005, Perkembangan Terapi Diare, In: Pusponegoro Hardiono et al (eds). Untuk Mereka Kita Bekerja, IDAI, Jakarta, pp. 15-18. 
Soeparto P et al, 1999, Gangguan Absorpsi-Sekresi Sindroma Diare, Gramik, Surabaya.

Soetjiningsih 1997, ASI Petunjuk Untuk Tenaga Kesehatan, EGC, Jakarta.

Sopiyudin, DM 2009, Statistik untuk Kedokteran dan kesehatan, Penerbit Salemba Medika, Jakarta.

Suharyono, Boediarso, A, Halimun, EM 1999, Gastroenterologi Anak Praktis, FKUI, Jakarta.

Wiryo, H 2005, Makanan Pendamping ASI dini di Indonesia, In : Pusponegoro Hardiono et al (eds). Untuk Mereka Kita Bekerja, IDAI, Jakarta, pp. 133-136. 